\title{
COVID-19 Tracking Applications: A Human-Centric Analysis
}

\author{
Merih Angin ${ }^{1}$, Pelin Angin ${ }^{2 *}$ \\ ${ }^{1}$ Koc University, Department of International Relations, Istanbul, Turkey, (ORCID: 0000-0003-0739-798X), mangin@ku.edu.tr \\ 2* Middle East Technical University, Department of Computer Engineering, Ankara, Turkey, (ORCID: 0000-0002-6419-2043), pangin@ @eng.metu.edu.tr
}

(First received 8 December 2020 and in final form 27 April 2021)

(DOI: 10.31590/ejosat.837359)

ATIF/REFERENCE: Angin, M., \& Angin, P. (2021). COVID-19 Tracking Applications: A Human-Centric Analysis. European Journal of Science and Technology, (23), 861-867.

\begin{abstract}
The year 2020 will always be remembered with the imprints left by COVID-19 on our lives. While the pandemic has had many undesirable effects for the whole world, one of its biggest side effects has been the fast digital transformation that has taken place, which was already in progress with the Industry 4.0 era. The readily available technology and wireless communications infrastructures paved the way for a myriad of digital technologies for the containment of the disease using mobile contact tracing applications developed by health authority organizations in many countries. The mounting privacy concerns especially with Bluetooth-enabled proximity tracing and centralized tracking technologies used by these applications have given rise to the development of new privacy-preserving contact tracing protocols. Although these new protocols have alleviated the privacy concerns of citizens to a certain extent, widespread adoption is still far from being the reality. In this paper, we analyze existing contact tracing technologies from a human-centric standpoint by focusing on their privacy implications. Based on our comprehensive dataset consisting of the contact tracing application usage information in 94 countries, and the corresponding World Bank's World Governance Indicators (WGI) data on political conditions, as well as World Values Survey (WVS) and European Values Study (EVS) data on confidence in government, we analyze our survey conducted on MTurk: the results demonstrate that privacy concerns are still the leading deterrent for people when deciding whether to use these applications. Nevertheless, it is a globally accepted argument that the most effective and fastest method for contact tracking will be digital technologies free from human errors and manual procedures. Accordingly, it is concluded that a policy of developing decentralized tracking solutions based entirely on user privacy should be followed, in which independent trusted third parties assume the role of authority in the system architecture, if absolutely necessary, in order to effectively combat the pandemic worldwide. An important feature of the systems to be developed to pave the way for widespread use is to provide the users the right to be forgotten.
\end{abstract}

Keywords: COVID-19, contact tracing, privacy.

\section{COVID-19 Takip Uygulamaları: İnsan Odaklı Bir Analiz}

$\ddot{\mathbf{O z}}$

2020 yılı, COVID-19'un hayatımızda bıraktığı izlerle her zaman hatırlanacaktır. Pandeminin tüm dünyada istenmeyen birçok etkisi olurken, en büyük yan etkilerinden biri Endüstri 4.0 çağıyla birlikte halihazırda devam eden dijital dönüşümün hızlanması olmuştur. Kullanıma hazır teknoloji ve kablosuz iletişim altyapıları, birçok ülkede sağlık otoritesi kuruluşları tarafından geliştirilen mobil temaslı takip uygulamalarını kullanarak hastalığın kontrol altına alınması için sayısız dijital teknolojinin önünü açmıştı. Özellikle Bluetooth tabanlı yakınlık takibi ve temaslı takip uygulamaları tarafindan kullanılan merkezi izleme teknolojileri nedeniyle artan mahremiyet endişeleri, gizliliği koruyan yeni temaslı takip protokollerinin geliştirilmesine yol açmıştır. Bu yeni protokoller, vatandaşların mahremiyet kaygılarını bir dereceye kadar hafifletmiş olsa da, yaygın olarak benimsenmeleri hala gerçeklik olmaktan

*Corresponding Author: pangin@ @eng.metu.edu.tr 
uzaktır. Bu çalışma, mevcut temaslı takip teknolojilerini, gizlilik etkilerine odaklanarak insan merkezli bir bakış açısından analiz etmektedir. 94 ülkedeki temas izleme uygulaması kullanım bilgileri ve ilgili Dünya Bankası'nın siyasi koşullara ilişkin World Governance Indicators (WGI) verilerinin yanı sıra World Values Survey (WVS) ve European Values Study’nin (EVS) hükümete güven üzerine verilerinden oluşan kapsamlı veri setimize dayanarak MTurk'te yaptığımız anketi analiz etmekte; sonuçlar gizlilik endişelerinin, bu uygulamaları kullanıp kullanmamaya karar verirken insanlar için hala önde gelen caydırıcı unsur olduğunu göstermektedir. Bununla beraber, temaslı takibi için en etkin ve hılı yöntemin yine insan hatalarından ve manuel prosedürlerden uzak dijital teknolojiler olacağı dünya genelinde kabul gören bir argümandır. Bu bağlamda tüm dünyada pandemiyle etkin mücadele için mutlaka gerekliyse bağımsız güvenilir üçüncü tarafların sistem mimarisinde yetkili rolünü üstlendiği, tamamen kullanıcı gizliliği üzerine dayalı, merkezi olmayan takip çözümlerinin geliştirilmesi politikası izlenmesi gerektiği sonucuna varılmıştır. Yaygın kullanımın önünü açmak için geliştirilecek sistemlerin sahip olması gereken önemli bir özellik de, kullanıcılara sistem tarafından unutulma hakkını sağlaması olacaktır.

Anahtar Kelimeler: COVID-19, temasli takibi, mahremiyet.

\section{Introduction}

2020 will undoubtedly go down in history as the year when one of the world's fiercest epidemics erupted. If there is one clear lesson the COVID-19 pandemic has taught the humankind, that must be the significance of information sharing. The epidemic that started spreading from China could have been eradicated had there been more transparency both at the domestic and international level. As the virus continued to spread fast, the stringency of the precautions also intensified: many countries closed their borders, stopped domestic and international flights and declared a state of emergency. Although computer models for estimating the spread of the pandemic were successful (Sevli and Başer, 2020), countries were not as successful in their fight against the pandemic. A common measure taken by more than a hundred countries was the release of digital COVID-19 tracking applications. While COVID-19 tracking applications can focus on a variety of tasks, their most popular use is in the field of contact tracing, which is a surveillance strategy utilized to prevent the spread of an infectious disease (Osman et al., 2020).

At a high level, contact tracing applications aim to create digital records of the interactions between people who have been in close proximity to each other in order to alert them about potential infection risks and/or retroactively warn them about contact with people who were later diagnosed with the infection. While worldwide digital transformation will continue to create opportunities for more effective contact tracing than humans alone can achieve using manual techniques (Whitelaw et al., 2020), the security and privacy risks associated with the underlying technologies have already caused a divergence between people taking a "privacy-first" vs "data-first" view (Fahey and Hino, 2020; Sabat et al., 2020). Major concerns associated with the applications include privacy violations by eavesdroppers, contacts and authorities (Cho et al., 2020) in addition to other ethical and legal concerns (Gasser et al., 2020), as well as accuracy problems that could lead to many false positives or false negatives (Sweeney, 2020). In actual fact, the concerns regarding ethical governance of the digital transformation extend beyond the pandemic, deterring people from utilizing the contact tracing applications with the fear that the gathered data may be used against them even after the pandemic ends (Taddeo, 2020). This adds to the ethical dilemma between making application download voluntary (Klar and Lanzerath, 2020) vs mandatory for increased efficacy. Adaptive governance will be an important aspect for governments to take into consideration in order to increase social acceptability of the applications (Blasimme and Vayena, 2020).

The effectiveness of COVID-19 tracking applications will not only depend on the accuracy of proximity estimation and how advanced the utilized technologies are, but also on the social acceptability of the applications (Georgieva et al., 2020). Aware of the fact that utilization rates of digital contact tracing applications will largely depend on people's sentiments regarding these applications, a number of country-level studies have been conducted in various countries including India (Garg et al., 2020), Republic of Ireland (O'Callaghan et al., 2020), Poland (Wnuk et al., 2020), Belgium (Walrave et al., 2020), Australia and Singapore (Wollongong and Michael, 2020; Goggin, 2020). However, with a diverse sample of respondents not limited to a particular region or country, researchers can detect patterns in responses that are not affected by country characteristics.

In this paper we provide a human-centric analysis of COVID-19 tracking applications by first discussing the various underlying proximity tracing technologies they utilize and their privacy issues, followed by a multinational survey on people's sentiments regarding COVID-19 tracking applications. The remainder of this paper is organized as follows: In Section 2, we provide technical background on the different technologies used for COVID-19 proximity tracing, describe our extensive dataset of worldwide pandemic tracking applications and the design of the survey we have conducted regarding people's sentiments about these applications. Section 3 discusses our findings about the acceptance of pandemic tracking applications and Section 4 concludes the paper with recommendations on what the tracking technologies need to focus on for wider adoption.

\section{Material and Method}

\subsection{COVID-19 Tracking Technologies}

In this section we provide an overview of the main technologies used in COVID-19 contact tracing applications. Although the used technologies and tracking protocols may have variances in different tracking applications, the general working principle is similar in all. Based on the system architecture, we can categorize the applications as centralized vs decentralized (Ahmed et al., 2020). In a centralized tracking system, users register their devices with a central authorized server, which creates a temporary identifier for the device, encrypted with a secret key generated by the central server and communicated to the device. Users of the application exchange the generated 
identifiers when they are within a certain proximity of each other. The users are notified of the risk when they are close to a disease carrier by passing the exchanged identifiers to the central server, which has global knowledge of the infected users. Depending on the laws and regulations in place, the use of the application by infected individuals can be voluntary or mandatory, achieving a more effective global knowledge base in the latter case.

On the other hand, in a decentralized tracking system, the main functionality of the system is moved to user devices rather than a central server. This architecture obviates the need for registration with a central authority and uses randomly generated, timestamped privacy-preserving pseudonyms instead of the real identities of the users, which are exchanged with other devices in close contact. Infected users may also upload their random seeds to a central server, in which case the central server acts like a meeting point that does not know the identities of the infected individuals, but just acts as a relay for other devices to check whether they have been in close proximity of infected users.

The central element of any pandemic tracking application is a module that is capable of tracing the proximity of individuals using the application in order to alert other users and/or the state about the presence of a disease carrier within a certain distance. At a high level, these proximity tracing technologies can be categorized as geolocation/GPS-based technologies vs. Bluetooth-enabled tracking technologies and its variants. While early contact tracing applications relied mainly on GPS-based and simple Bluetooth-based tracking or a combination of the two, mounting privacy concerns during the pandemic led to the development of new privacy-preserving proximity tracing protocols including DP3T (Decentralized Privacy-Preserving Proximity Tracing), PEPP-PT (Pan-European Privacy-Preserving Proximity Tracing), Google/Apple Exposure Notification project among others.

\subsubsection{Geolocation/GPS}

GPS-based tracking has been a popular means of locating individuals in a variety of applications with increasing accuracy in the past decade. While GPS-based tracking enables identifying the whereabouts of an application user within a certain error margin in outdoor locations, its effectiveness is much more limited in indoor locations, making it fail in the highly accurate proximity tracing tasks required by COVID-19 tracking applications. Another major problem with GPS-based tracking in the context of COVID-19 is the privacy concerns arising from the transfer of the absolute geolocation of individuals to a central server in the case of a centralized application architecture.

\subsubsection{Bluetooth}

The Bluetooth technology has been supported by mobile devices for a long while, dating back to times before the introduction of smartphones. Proximity estimation using Bluetooth on modern mobile devices is achieved by capturing the Received Signal Strength Indicator (RSSI) values (Liu et al., 2014) of wireless signals emitted by the devices, as the attenuation of signals increases with increasing distance enabling approximate distance calculations. As these signals can be greatly affected by the presence of other objects in the environment, Bluetooth-based proximity tracing by itself does not offer a bullet-proof solution and may need to be used in combination with other technologies like GPS to achieve more accurate results. Most modern devices utilize a low power mode of Bluetooth communication, which is called Bluetooth Low Energy (BLE) to prevent fast battery drainage. In its simplest form, BLE communication is vulnerable to various attacks on privacy. In an effort to alleviate privacy issues, security researchers have created a variety of protocols during the pandemic, relying mainly on BLE, but enhancing the privacy of data exchanges and storage. The most commonly used protocols among these are explained below.

\subsubsection{PEPP-PT (Pan-European Privacy-Preserving Proximity Tracing)}

Pan-European Privacy-Preserving Proximity Tracing (PEPP-PT $)^{\dagger}$ is an open protocol that uses BLE for discovery of users within the proximity of an application user, reports contact logs to a central server and notifies application users of possible contact with infected individuals. Users are authenticated during registration to the system in order to prevent creation of multiple fake accounts. However, instead of relying on personally identifiable information (PII), the protocol utilizes 128-bit pseudorandom IDs issued by the server, which are activated upon solving a proof-of-work (PoW) puzzle as in many blockchain systems (Aydar and Çetin, 2020) and a CAPTCHA on the application. The communication between user devices within close proximity takes place as follows: Temporary timesensitive identifiers are created for each device by the central server, which utilizes a global temporary secret key to encrypt the users' pseudorandom IDs. These encrypted identifiers are exchanged between user devices upon close contact.

While the centralized architecture of PEPP-PT has been widely criticized especially by security researchers for privacy compromise, causing the abandonment of the protocol at large, verification by health authorities is an aspect that enhances the reliability of the system.

\subsubsection{DP3T (Decentralized Privacy-Preserving Proximity Tracing}

Decentralized Privacy-Preserving Proximity Tracing (DP3T) (Troncoso et al., 2020) is another BLE-based protocol for proximity tracing, which mainly differs from PEPP-PT in that it does not involve processing contact $\operatorname{logs}$ at a central server. Instead, infection reports are processed on the user devices themselves, which provides privacy benefits over PEPPPT. In DP3T, 16-byte Ephemeral IDs that uniquely identify users are exchanged between devices upon encounter and stored in the contact $\log$ of each device. Infection cases are reported to a central server and devices collect these reports from the server to check whether the Ephemeral IDs in their contact log appear in the report. By delegating the contact log processing process to user devices, DP3T achieves enhanced privacy when compared to the much-criticized PEPP-PT, at the expense of high battery usage and computation cost on the devices.

\subsubsection{Google/Apple Exposure Notification}

The Google/Apple Exposure Notification (GAEN) framework is a decentralized contact tracing protocol developed jointly by Apple and Google (Michael and Abbas, 2020), which also relies on BLE, but is implemented at the operating system

\footnotetext{
${ }^{+}$https://github.com/pepp-pt
} 
level to achieve increased efficiency by running as a background process. Tracking messages exchanged between devices in the framework contain unique IDs that change frequently, encrypted with the daily secret key of the sending device. Messages received by a device are stored for 14 days on the device and upon testing positive, a user can upload their daily encryption keys to a central server, from which they are disseminated to the whole network. GAEN is similar to DP3T in terms of privacy properties, however its availability is limited to countries where the two companies have enabled the API for use.

\subsection{COVID-19 Tracking Applications}

Since the start of the COVID-19 pandemic, many digital contact tracing applications have been developed worldwide, where most are controlled by states and some by local authorities. Martin et al. (2020) have composed a list of applications that have been deployed in Europe. However, the situation could vary widely in the world due to cultural, political and developmental differences as well as the level of access to technology. In an effort to provide an extensive resource on the adoption of COVID-19 contact tracing applications in the world, we have created a dataset that provides a detailed account of applications, download numbers, COVID-19 related figures such as COVID caused deaths, number of state-controlled applications and private applications, mobile cellular subscriptions etc. We merged our dataset with the World Bank's World Governance Indicators (WGI) data on political conditions in these countries such as regulatory quality, rule of law, government effectiveness and voice and accountability, as well as World Values Survey (WVS) and European Values Study (EVS) data on confidence in government. To our knowledge, our dataset is the most detailed source available, including information on 94 countries, and it is being updated regularly. Table 1 provides an excerpt from our dataset, with the first 5 rows showing data on countries which have the highest number of COVID-19 application downloads per capita, and the remaining rows showing data on countries which have the lowest number of COVID-19 application downloads per capita.

Table 1. Excerpt from worldwide COVID-19 tracking applications dataset

\begin{tabular}{|c|c|c|c|c|c|c|c|}
\hline Country name & $\begin{array}{c}\text { App } \\
\text { download } \\
\text { per capita }\end{array}$ & $\begin{array}{c}\text { \# of State } \\
\text { Controlled } \\
\text { Apps } \\
\end{array}$ & $\begin{array}{c}\text { App } \\
\text { download } \\
\text { compulsory } \\
\text { or not } \\
\end{array}$ & $\begin{array}{c}\text { \# of State } \\
\text { Controlled } \\
\text { App } \\
\text { Downloads } \\
\end{array}$ & $\begin{array}{c}\text { \# of } \\
\text { Private } \\
\text { Apps } \\
\end{array}$ & $\begin{array}{l}\text { Mobile cellular } \\
\text { subscriptions } \\
\text { (per 100 } \\
\text { people) } \\
\end{array}$ & $\begin{array}{c}\text { WGI Rule of } \\
\text { Law }\end{array}$ \\
\hline Qatar & 0.359495369 & 1 & yes & 1000000 & 0 & 141.86 & 0.73 \\
\hline $\begin{array}{l}\text { Brunei } \\
\text { Darussalam }\end{array}$ & 0.230794973 & 1 & yes & 100000 & 0 & 131.93 & 0.63 \\
\hline Iceland & 0.141755098 & 1 & no & 100000 & 0 & 126.14 & 1.72 \\
\hline Israel & 0.135092538 & 1 & no & 1000000 & 2 & 127.66 & 0.99 \\
\hline Bhutan & 0.132356256 & 2 & yes & 105000 & 0 & 93.26 & 0.55 \\
\hline South Africa & $1.73071 \mathrm{E}-06$ & 1 & & 500000 & & 159.93 & -0.10 \\
\hline Ghana & $1.67971 \mathrm{E}-05$ & 1 & . & 5000 & 0 & 137.52 & 0.07 \\
\hline Uzbekistan & $3.0344 \mathrm{E}-05$ & 1 & No & 5000 & 0 & 71.52 & -1.07 \\
\hline Sri Lanka & 4.61467E-05 & . & No & 10000 & 1 & 142.65 & 0.03 \\
\hline Philippines & $4.68815 \mathrm{E}-05$ & 1 & . & 100000 & 1 & 126.20 & -0.48 \\
\hline
\end{tabular}

\subsection{Survey on Sentiments Regarding COVID-19 Tracking Technologies}

In order to understand the sentiments of people from different countries regarding COVID-19 tracking applications as well as the reasons behind their preferences when using or not using an application, we have conducted a survey study on Amazon's Mechanical Turk ${ }^{\star}$ crowdsourcing platform. Below we describe our survey method and measures.

\subsubsection{Method}

Participants: Survey respondents were recruited through Amazon's Mechanical Turk (MTurk), with no specified restrictions of residency, giving us a global sample. The participant identities are completely anonymous, as MTurk does not provide identity information.

${ }^{\ddagger}$ https://www.mturk.com/
To determine opinions on COVID-19 tracking applications, MTurk respondents interested in the study completed a 7question survey via Qualtrics. The first 6 questions appeared on the first page, and each of these questions were mandatory to be answered in order to see the next page. For respondents selecting "yes" for question 6 that asked "Have you downloaded the COVID-19 Tracking App(s) available in your country of residence?", the externally-linked survey was programmed to ask "What are the reasons that led you to download the app (Please select all that apply):". Respondents who selected "no" for question 6 received the following question instead: "What are the reasons that led you NOT to download the app (Please select all that apply):".

The estimated time to complete the survey was 2 minutes. Upon successful completion of the survey respondents received $\$ 0.25$. We determined this amount according to the minimum hourly wage in the US, which is $\$ 7.25$ per hour. Since the reward was well above the average hourly wage for tasks performed on MTurk, our survey was completed fully on the day 
it was published. This way we are able to control for any exogenous shocks that could affect the responses.

\subsubsection{Measures}

\section{Demographic questions:}

The survey asked participants to give basic demographic information about their age, gender and education level. We expected each of these 3 variables to have some explanatory power on the decision to download the COVID-19 tracking applications.

\section{Living conditions questions:}

Next the survey asked the respondents whether they lived alone. For the purposes of this study, it was important to assess the respondents' level of contact with their surroundings, specifically whether they were living alone at the time of the study, which may explain the underlying reason for not downloading COVID-19 tracking applications. In this regard, the following question was asked: "How often have you gone out of your house on average since the beginning of the pandemic?". We expected respondents who go out more often to be more willing to download COVID-19 tracking applications.

\section{Opinions on COVID-19 tracking applications:}

The sixth question of the survey asked the respondents to answer whether they downloaded a COVID-19 tracking application or not. For those who said "yes", the following notmutually-exclusive options were given to explain the reason that led them to download the application:

- Concern about being in close proximity to COVID-19 carriers

- It was enforced by the government

- Out of curiosity

- I carry/carried COVID-19 and wanted to avoid spreading the virus

- Other reasons

To the respondents who said "no", the following notmutually-exclusive options were given to explain the reason that led them not to download the application:

- I don't trust the government with my personal data

- I don't want to share such personal data due to privacy concerns

- The app might have cyber security vulnerabilities

- The app drains the phone battery

- I carry/carried COVID-19, and didn't want to be spotted in the app

- I don't think it is useful

- I didn't know such an app existed in my country

- Such an awareness would cause stress for me

- Others

\section{Results and Discussion}

309 respondents submitted their surveys on November 22, 2020 , which is also the date of the survey's publication on MTurk. Of these participants, $21.04 \%$ were aged between 18-25,
$32.09 \%$ were between $26-35,16.50 \%$ were between $36-45$, $21.68 \%$ were aged between $46-60$ and $8.09 \%$ were over 61 years old. Like most surveys conducted on MTurk, our respondents mostly had a college/university degree $(63.11 \%)$. Only $1.94 \%$ of the respondents had a middle school degree, while $8.41 \%$ had a high school degree.

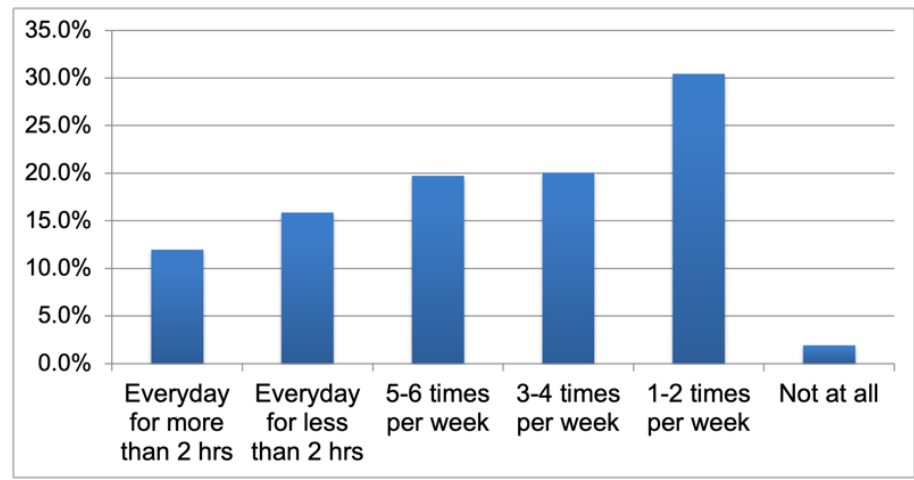

Figure 1. Responses to question 5

For the question asking if the participant lives alone, $48.22 \%$ of the respondents said "yes", and $51.78 \%$ said "no". Figure 1 graphs the distribution (in percentage) of the participant's response to the question asking: "How often have you gone out of your house on average since the beginning of the pandemic?

For question 6 , asking if the respondent has downloaded the COVID-19 tracking app(s) available in his/her country of residence, $23.30 \%$ said "no". Figure 2 shows the distribution (in percentage) of the reasons for downloading the application(s), selected by the respondents who answered "yes".

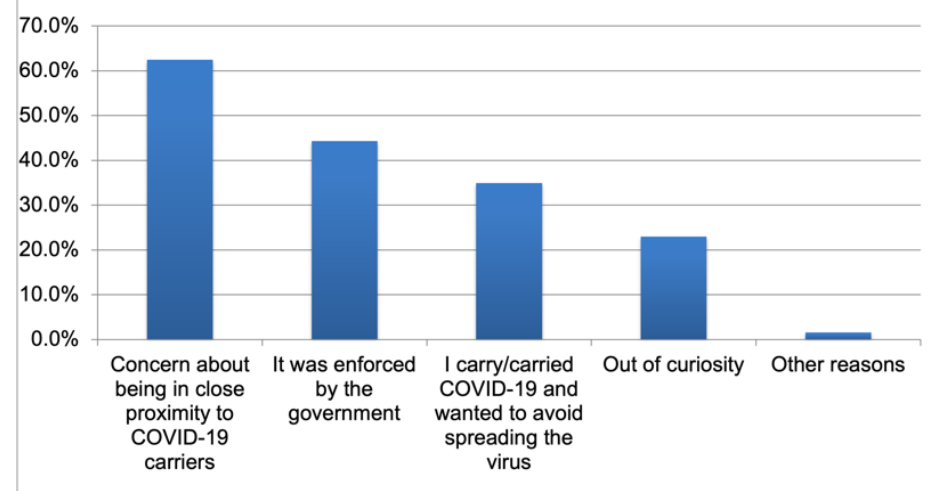

Figure 2. Responses of the participants who said "yes" to question 6

$37.55 \%$ of the respondents downloaded an application because they were concerned about being in close proximity to COVID-19 carriers, and $26.65 \%$ of the respondents downloaded because it was enforced by their government. This is an important finding, since only $8.5 \%$ percent of the countries in our dataset enforce application downloads. $21.01 \%$ of the respondents downloaded an application due to carrying COVID19 and thus wanting to avoid spreading the virus. $13.81 \%$ of the respondents downloaded an application out of curiosity. Only $0.97 \%$ indicated other reasons, which are listed below:

"I think everyone should feel more responsible and more concerned about what is going on."

"Common sense" 
"It was requested by the South African government and was explained in the general media as safe and helpful against the fight against Covid-19."

"to know severity of covid-19"

Figure 3 graphs the distribution (in percentage) of the reasons for not downloading the application(s), selected by the respondents who answered "no".

The most common concern about COVID-19 tracking applications appears to be that of privacy: $20.12 \%$ of the respondents indicated that they do not want to share such personal data. $17.16 \%$ of the respondents do not trust their government with their personal data, and $14.20 \%$ believe the application might have cyber security vulnerabilities. $13.61 \%$ of the respondents were simply not aware of the existence of COVID-19 tracking application(s) in their country, and another $13.61 \%$ of the respondents do not find the applications useful. Although only a small percentage, a concerning $4.73 \%$ of the respondents indicated that they did not download the application because they carried COVID-19, and did not want to be spotted in the application. If these respondents did not pay much heed to taking other necessary precautions to contain the virus, they must have infected their surroundings. It also appears that some people simply do not want to know about the COVID-19 carriers in close proximity: $6.51 \%$ of the respondents think that such an awareness would cause stress for them. $7.1 \%$ underlined the application draining their phone's battery as a reason for not downloading it. Only $2.96 \%$ indicated other reasons, which are listed below:

"In Italy it doesn't work very well."

"Due to Trump, his Administration and Republican's misinformation I don't think this app would be that much helpful for now...,"

"I might have problems as I work with many people"

"I don't know how accurate the data is."

"Phone memory full."

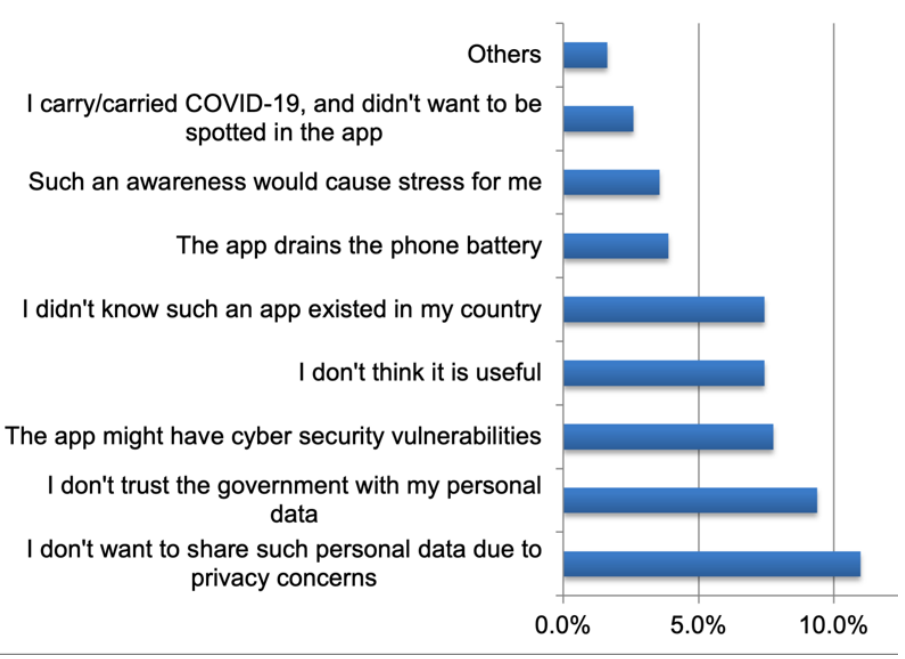

Figure 3. Responses of the participants who said "no" to question 6

Since the purpose of this study is not statistical inference from a large-N study, we do not employ statistical regression on our sample, we instead visualize the distribution of responses in different demographic groups. Figure 4 shows the distribution of age groups based on their responses to question 6 .

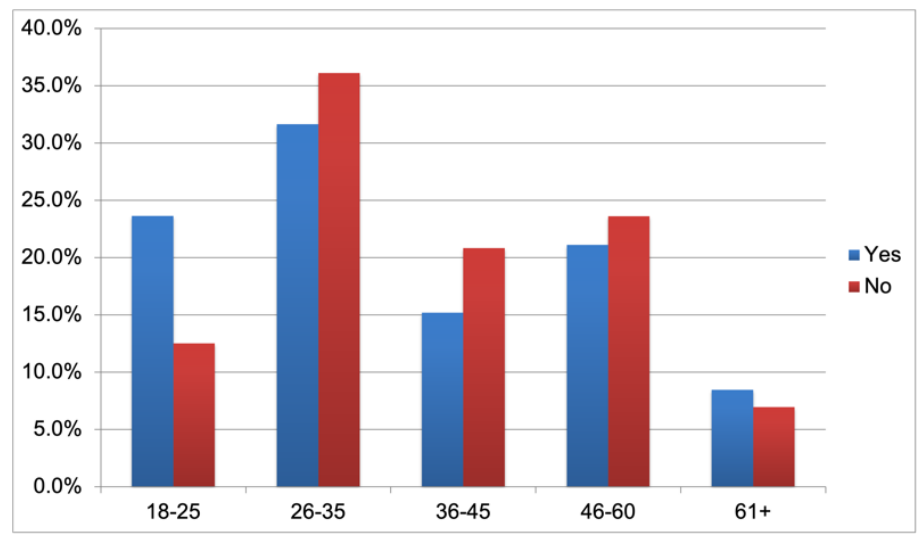

Figure 4. Distribution of age groups based on their responses to question 6

Figure 5 shows the distribution of different education level groups based on their responses to question 6 .

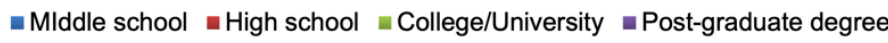

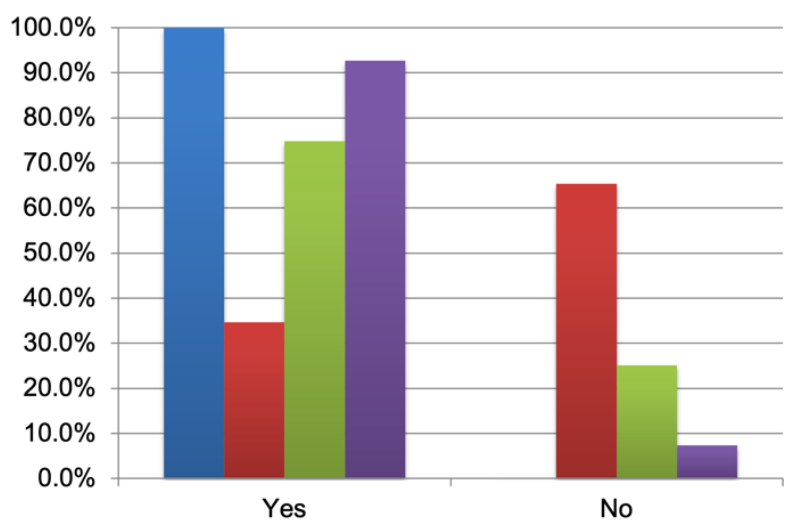

Figure 5. Distribution of different education level groups based on their responses to question 6

Apart from a negligible $0.94 \%$ of the respondents in the first category of education level, we do observe an increasing trend in application downloads as the education level goes up.

\section{Conclusions and Recommendations}

History has taught us the importance of exchange of knowledge in fighting epidemics. The most significant difference between the precautions taken against the 1918 Spanish flu pandemic and the fight against the Coronavirus today should be the usage of advanced technologies such as COVID-19 tracing applications. However, technological advancement can only be useful if it is indeed used by the mass population, which has not been the case with COVID-19 contact tracing applications. Our study demonstrates that people who do not download these applications are mostly those with privacy concerns, and those who do not trust their government with their personal data. This finding opens up a new avenue of research on the evolution of state-citizen relationship, which we aim to explore with our novel dataset that we also utilized in this study. Trust in government is a key aspect in this regard. Since trust cannot be established straightforwardly, alternative measures to remedy the lack of trust in the system could be developed as a solution. An independent international organization, such as 
World Health Organization could be a potential hub for collecting data. Societies that historically have had a low level of trust in institutions may not benefit from the same policy instruments used in countries with a higher level of trust in the system. People living in countries with a lower score of rule of law, regulatory quality, government effectiveness and accountability may refrain from sharing their personal data regardless of the technology used to ensure cyber security vulnerabilities. In such cases, a third party that is not only considered as a neutral body, but also has a certain degree of credibility could fill the void. Nevertheless, these trusted third parties will also vary from country to country. Therefore, the development of technologies in this context should take the country characteristics into account.

When decentralized system architectures are considered, use of blockchain seems like an effective solution for contact tracing, and has been proposed by many researchers. In the case of blockchain technology, one potential issue to tackle would be the right to be forgotten. The General Data Protection Regulation (GDPR) gives the European Union residents the right to ask organizations to delete their personal data, however, blockchains provide immutable histories of transactions that have taken place in their lifetime. The right to be forgotten is an important aspect for the widespread adoption of contact tracing applications, as the data stored is sensitive, and a permanent record could be a major deterrent for potential users of the application. In conclusion, it is vital to create tailor-made policies rather than a one-size-fits-all approach for effective and socially acceptable contact tracing.

\section{References}

Abbas, R. \& Michael, K. (2020). COVID-19 contact trace app deployments: learnings from Australia and Singapore. IEEE Consumer Electronics Magazine, 9(5). 65-70.

Ahmed, N., Michelin, R. A., Xue, W., Ruj, S., Malaney, R., Kanhere, S. S., ... Jha, S. K. (2020). A survey of Covid-19 contact tracking apps. IEEE Access, 8, 134577-134601.

Aydar, M. \& Çetin, S. C. (2020). Blokzincir Teknolojisinin Sağlık Bilgi Sistemlerinde Kullanımı. Avrupa Bilim ve Teknoloji Dergisi, (19), 533-538.

Blasimme, A. \& Vayena, E. (2020). What's next for COVID-19 apps? Governance and oversight. Science, 370(6518), 760762.

Cho, H., Ippolito, D. \& Yu, Y. W. (2020). Contact tracing mobile apps for Covid-19: Privacy considerations and related tradeoffs. arXiv:2003.11511v2 [cs.CR]

Fahey,R.A. \& Hino, Airo. (2020). Covid-19, digital privacy, and the social limits on data-focused public health responses. International Journal of Information Management, 55, https://doi.org/10.1016/j.ijinfomgt.2020.102181

Garg, S., Bhatnagar, N. \& Gangadharan, N. (2020). A case for participatory disease surveillance of the Covid-19 pandemic in India. JMIR Public Health and Surveillance, 6(2), doi:10.2196/18795

Gasser, U., Ienca, M., Scheibner, J., Sleigh, J. \& Vayena, E. (2020). Digital tools against COVID-19: Framing the ethical challenges and how to address them. Health Policy, 2(8), e425-e434.

Georgieva, I., Beaunoyer, E. \& Guitton, M. J. (2020). Ensuring social acceptability of technological tracking in the Covid19 context. Computers in Human Behavior, 116, 1-8.

Goggin, G. (2020). COVID-19 apps in Singapore and Australia:

e-ISSN: 2148-2683 reimagining healthy nations with digital technology. Media International Australia, 177(1), 61-75.

Hargittai, E., Redmiles, E. M., Vitak, J. \& Zimmer, M. (2020). Americans' willingness to adopt a COVID-19 tracking app: The role of app distributor. First Monday, 24(11), https://dx.doi.org/10.5210/fm.v25i11.11095.

Klar, R. \& Lanzerath, D. (2020). The ethics of COVID-19 tracking apps- challenges and voluntariness. Research Ethics, 16(3-4), 1-9.

Liu, S., Jiang, Y. \& Striegel, A. (2014). Face-to-face proximity estimation using Bluetooth on smartphones. IEEE Transactions on Mobile Computing, 13(4), 811-823.

Martin, T., Karopoulos, G., Hernández-Ramos, J. L., Kambourakis, G. \& Fovino, I, N. (2020). Demystifying COVID-19 digital contact tracing: A survey on frameworks and mobile apps. Wireless Communications and Mobile Computing, 2020, 1-29.

Michael, K. \& Abbas, R. (2020). Behind COVID-19 contact trace apps: the Google-Apple partnership. IEEE Consumer Electronics Magazine, 9(5). 71-76.

O’Callaghan, M.E., Buckley, J., Fitzgerald, B., Johnson, K., Laffey, J., McNicholas, B., ... Glynn, L. (2020). A national survey of attitudes to COVID-19 digital contact tracing in the Republic of Ireland. Irish Journal of Medical Science, https://doi.org/10.1007/s11845-020-02389-y

Osman, M., Fenton, N. E., McLachlan, S., Lucas, P., Dube, K., Hitman, G. A., ... Neil, M. The thorny problems of Covid-19 contact tracing apps: The need for a holistic approach. Journal of Behavioral Economics for Policy, 4, 43-59.

Sabat, I., Neuman-Böhme, S., Varghese, N. E., Barros, P. P., Brouwer, W., Van Exel, J., ... Stargardt, T. United but divided: Policy responses and people's perceptions in the EU during the COVID-19 outbreak. Health Policy, 124(9), 909-918.

Sevli, O. \& Başer, V. G. (2020). Covid-19 Salgınına Yönelik Zaman Serisi Verileri ile Prophet Model Kullanarak Makine Öğrenmesi Temelli Vaka Tahminlemesi. Avrupa Bilim ve Teknoloji Dergisi, (19), 827-835.

Sweeney, Y. (2020). Tracking the debate on COVID-19 surveillance tools. Nature Machine Intelligence, 2, 301-304.

Taddeo, M. (2020). The ethical governance of the digital during and after the COVID-19 pandemic. Minds and Machines, 30, 171-176.

Troncoso, C., Payer, M., Hubaux, J.-P., Salathe, M., Larus, J., Bugnion, E., ... Pereira, J. (2020). Decentralized privacypreserving proximity tracing. arXiv:2005.12273 (cs.CR).

Urbaczewski, A. \& Lee, Y. J. (2020). Information technology and the pandemic: a preliminary multinational analysis of the impact of mobile tracking technology on the COVID-19 contagion control. European Journal of Information Systems, 29(4), 405-414.

Walrave, M., Waeterloos, C. \& Ponnet, K. (2020). Adoption of a contact tracing app for containing COVID-19: A health belief model approach. JMIR Public Health and Surveillance, 6(3), 1-10.

Whitelaw, S., Mamas, M. A., Topol, E. \& Van Spall, H. G. C. (2020). Applications of digital technology in COVID-19 pandemic planning and response. Lancet Digital Health, 2, e435-e440.

Wnuk, A., Olesky, T., Maison, D. (2020). The acceptance of Covid-19 tracking technologies: The role of perceived threat, lack of control, and ideological beliefs. PLOS ONE, 15(9), 1-16. 